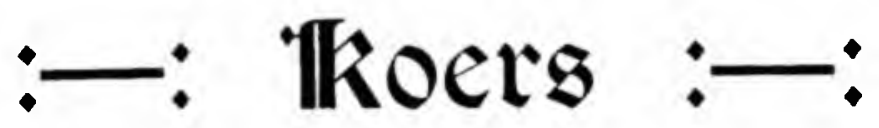

TWEEMAANDELIKSE TYDSKRIF.

\begin{tabular}{llll}
\hline \hline DEEL XVIII. & No. 2. & OKTOBER. & 1950. \\
\hline \hline
\end{tabular}

\title{
JESUS EN DIE KANON VAN DIE OU TESTAMENT.*
}

(*Kort opsomming van die proefskrif van dr. S. J. du Plessis).

Dit is moontlik om die kanon van die Ou Testament van verskillende kante te belig: van die kant van die Ou Testament self om daarin te soek watter gegewens oor die kanon te vind is; of vanuit buite-Bybelse bronne bv. die geskiedenis, apokriewe, rabbinistiese literatuur, Helleniste, apostoliese vaders, kerkvaders, die kerkgeskiedenis ens.; of vanuit die Nuwe Testament, hetsy ons die hele Nuwe Testament in aanmerking neem of slegs ' $n$ deel daarvan soos die Evangelies. Maar dit sal altyd van besondere belang bly om te weet wat Jesus, ons hoogste Profeet en Leraar, oor die kanon van die $\mathrm{Ou}$ Testament getuig het. Immers ons bekendheid met die Ou Testament gaan op Jesus terug. Geen ander persoon het die Ou Testament tot so 'n werkende mag in die geskiedenis van die mensheid gemaak nie. Met Jesus het ook die onderskeiding van Ou en Nuwe Verbond begin. Die besinning oor die stelling wat Jesus teenoor die Ou Testament ingeneem het, behoort daarom nie maar ' $n$ aanhangsel by een of ander beskouing oor die Ou Testament te wees nie, maar die eerste taak. Dit is van grondleggende betekenis. 1)

Die woord „kanon" sluit twee elemente in, nl. dié van 'n versameling boeke, wat gesagvol is. 2) In die eerste plaas gee ons dan aandag aan die versameling en dan vra ons na die name wat Jesus aan die versameling gegee het; die waarskynlike omvang van die versameling volgens 
Jesus; watter aanduidinge daar van ' $n$ indeling (in besonder driedeling) in die kanon van Jesus is en of 'n rekonstruksie van die rangskikking van die boeke in sy Bybel gemaak kan word; watter tekskarakter die $\mathrm{Ou}$ Testament van Jesus gedra het en of die versameling boeke as ' $n$ afgeslote eenheid voor Hom gelê het, dan wel as 'n ope kanon waar van tyd tot tyd nog boeke bygevoeg kon word. In die tweede plaas kom aan die orde die gesag van die versameling boeke en dan ondersoek ons (volgens Jesus) die aanduiding van gesag (as daar is) wat lê in die name, benaminge en aanhalingsformules wat $\mathrm{Hy}$ vir die $\mathrm{Ou}$ Testament gebruik; waarin $\mathrm{Hy}$ die oorsprong van die gesag gesien het-die inspirasie; of daar 'n einde gekom het aan die duur van dié gesag-duur van die Skrifnorm; of daar vir Hom 'n differensiasie in die norm bestaan het, sodat ons grade van geldigheid vind; en watter hermeneutiese metodes Christus toegepas het by die uitleg van die Skrifte, want daaruit sal blyk hoé die norm in praktyk gebring is. As noodsaaklike aanvulling van so 'n ondersoek word in 'n derde deel gevra na die betekenis en waarde van die woorde van Jesus betreffende die kanon van die Ou Testament: Watter gesag dra Hy Self?

\section{A. DiE VERSAMELiNG.}

\section{Die Name: :}

By die ondersoek van die name moet ons rekening hou met die ontwikkeling van die Griekse taal uit die klassieke Grieks, deur die Griekse vertaling van die Ou Testament, tot die Nuwe-Testamentiese Grieks. 3) Hierby moet ons in aanmerking neem dat die Grieks van die Nuwe Testament, die sgn. „geemeenskaplike” Grieks, 'n volks- en omgangstaal was. 4) Hierdie taal is deur die meeste skrywers van die Nuwe Testament nie uit boeke geleer nie, maar hulle het dit gehóór en dit bepaal hulle skryfwyse. 5) Verder moet nie vergeet word nie dat die omgangstaal in die mond van Jode gekleur is deur die Aramees as landstaal, 6) en dat die taal ook sekere veranderinge ondergaan het as openbaringstaal van die Nuwe Verbond. 7) Op die agtergrond van die Nuwe Testament en sy taal, staan nog altyd die Ou Testament en die gebruik van sekere woorde en begrippe by die rabbinistiese geleerdes is ook nie sonder betekenis vir die bepaling van die betekenis van 'n woord in die Nuwe Testament nie. Het ons dit alles in aanmerkinng geneem dan kan ons vasstel wat die betekenis van 'n besondere naam in die mond van Jesus was.

a. „Geskrifte (grammata), nie noodwendig 'n kanonieke begrip in Johannes 5: 47 nie. 
b. "Skrif" (grafê) is gelyk aan Skrifteks (Markus 12: 10=Psalm 118: 22), Skrifgeheel (Johannes 10: 35b waar "Skrif" 'n terugslag is op "wet" in vs. 34 en laasgenoemde op die hele Ou Testament sien, 8) en Skrif in sy geheel, naamlik uitdrukking van 'n deurlopende Skrifgedagte 9) (Johannes $7: 38$, vgl. Jesaja $55: 11 ; 58: 11$; Esegiël 36 ; 45 ; Joël 2: 23 : Sagaria 13: 1; Spreuke 5: 16. 10)

„Skrifte" (grafai): Dit is opmerklik dat in ooreenstemming met die gebruik by Philo, die rabbyne, die ou Christelike gemeentes, dog in teëstelling met die latere Jode, Jesus die benaming "Skrifte," sónder die byvoeging van die attribuut ,heilige," gebruik vir die boeke van die Ou Testament nl. Mattheüs 26: $54 ; 22: 29$; Johannes 5: 39; 8: 56; Markus 14: 19; Lukas 9: 35. 11)

c. „Wet" (nomos) is vir Jesus gelyk aan „wet van Moses” (Mattheüs 12: 5; Lukas 10: 26; Johannes 7: 19 en 23); die héle Ou Testament (Johannes 10: 34 en 15: 25); die hele Ou Testament in sy tweedeling (want in Mattheüs 22: 36 is "wet" gelyk aan "wet en profete" in vs. 40), en dele van die Ou Testament buite die wet van Moses (bv. in Mattheüs 23: 23 is die "swaarste van die wet," die „reg," „barmhartigheid" en „trou" 'n terugslag op Psalm 33: 5; Hosea 6: 6 en Jeremia 5: 1 respektiewelik en wat al drie saam betref op Sagaria $7: 9.12$ ) Nooit egter word „nomos" vir die mondelinge oorlewering gebruik nie. 13)

d. „Profete” (profêtai) beteken blykbaar al die Skrifte van die Ou Testament (Lukas 24: 25 vergelyk met vs. 27) en dis ongetwyfeld ook 'n kanonieke begrip in Johannes 6: 45 (vgl. „Dit is geskrywe in die Profete"):

e. „Die Wet en die Profete": Met dié woorde wou Jesus beslis nie twee dele van die kanon stel teenoor die derde wat nog nie gekanoniseer sou wees nie 14), maar ' $n$ aanduiding van die hele Ou Testament gee. In Matthelis 5: 17 is die bedoeling van Christus sekerlik dat Hy álles wil vervul. Met Mattheuls 7:12 word tog nie net op lie etiese voorskrifte in wet en profete nie, maar in ál die Skrifte, gesien. Vergelyk verder Mattheüs 22: 36 en 40 ; Lukas $16: 16 ; 29: 3$. 15)

f. „Die Wet en die Profete en die Psalms" (psalmoi) word deur Jesus in Lukas 24: 44 gebruik en die vraag is veral wat beteken "psalms" in dié verband. Met "Psalms" kan net die boek Psalms bedoel wees, omdat die ander boeke van die derde deel van die O.T. nog nie bestaan het of as kanoniek aangeneem is nie 16). Maar dit is 'n vraag wat nie op grond van dié teks alleen uitgemaak kan word nie. Bewys hiervoor moet elders gesoek word en dan op Lukas 24: 44 toegepas 
word. Net die boek Psalms kan bedoel wees omdat blykens die teksverband Christus veral spreek oor sy lyde en omdat oor die lyde van die Messias handel. 17) Vers 27 vergelyk met vers $44 \mathrm{~b}$ laat egter blyk dat nie net oor die lyde nie, maar oor alles, al die dinge wat op Hom betrekking het, gehandel word. Psalms alleen word genoem nie asof in dié boek alleen oor die Christus voorspellinge gedoen word nie, 18) want ook in die ander boeke wat algemeen tot die derde groep gereken word, is daar profesieë en tipes van Jesus, soms direk, soms indirek, voorhande. Ons kon Psalms verstaan as die aanduiding van die indiwiduele boek Psalms, maar dan word dit onverklaarbaar waarom "Wet" en „Profete” in hierdie samevoeging groépe van boeke aandui, maar „Psalms" nie. 19) Die moontlikheid bestaan dat Psalms hier gebruik word met verlies van sy tegniese betekenis en dus as 'n déél wat die geheel aandui-pars pro toto. 20) Maar ook dié opvatting gee geen volledige bevrediging nie, omdat „Wet" en „Profete" gehele eenhede aandui in die baie hegte frase; Wet, Profete, Psalms. Die Jode het die gewoonte gehad om 'n hele boek of groep aan te dui met die eerste woord van dié boek of groep en in dié sin mag Psalıns moontlik as eerste woord en daarom as aanduiding van die hele derde groep gebruik word. 21) Maar indien dit die geval is kan ons met reg verwag dat die wet met „In die begin" en die profete met „Josua" aangegee moes gewees het. 22)

Neem ons nou egter die Semitiese (Hebreeuse en Aramese) agtergrond van die Nuwe-Testamentiese taal en -skrywers in aanmerking, dan moet ons agter die woord „Psalms" die Hebreeuse of Aramese woord soek. Dit blyk dan dat dieselfde woord in die Aramees vir verskillende woorde in die Hebreeus gebruik word bv. dieselfde woord vir lof, loflied, himne, psalm ens. Wanneer dié Aramese woord nou vertaal word in die Grieks, kan in laasgenoemde taal wat meer sinonieme het vir dieselfde woord, die één Aramese woord of met „Psalms" (psalmoi) of met „himnes" (humnoi) vertaal word. Met ander woorde in Lukas 24: 44 kan ons ook lees en verstaan: wet, profete en himnes! 23) "Himnes" is dan 'n algemene benaming, analoog met die algemene benaminge "wet" en „profete," en sien dan op die boeke van die derde groep wat 'n himneof poëtiese karakter dra nl. Psalms, Spreuke, Prediker, Hooglied. Uit die geskrifte van Philo en Josephus weet ons juis dat dié twee skrywers die woorde „psalms” en ",himnes" as sinonieme gebruik en dat eersgenoemde "himnes" gebruik as aanduiding van die derde deel van die Ou-Testamentiese kanon. 24).

Met die woorde ,die Wet en die Profete en die Psalms" het Jesus dan ongetwyfeld die hele Ou Testament bedoel. 


\section{Die moontlike omvang van die kanon van Jesus.}

Buite-Bybelse bronne, soos die apokriewe (vir wat hulle getuienis werd mag wees), die berigte van Joodse skrywers (bv. Josephus en die kleinseun van Jesus Sirach) en die rabbinistiese literatuur 25) laat ons vermoed en verwag dat die kanon van Jesus van dieselfde omvang was as dié wat aan ons bekend is. Of Jesus inderdaad só 'n kanon geken en gebruik het, kan ons alleen aflei deur sy eie woorde te ondersoek.

Uitgaande van die woorde van Jesus kan ons 'n tabel opstel wat aantoon hoe Jesus van die Ou Testament gebruikmaak. Uit só 'n tabel sal dit duidelik word watter boeke wél en watter boeke nié deur Jesus gebruik is nie. Dit sal ons ' $n$ aanduiding van die omvang van sy kanon gee. Dit is al dadelik duidelik dat Jesus op verskillende maniere van die verskillende boeke en verse in die Ou Testament gebruik sou maak. Die verhoudinge tussen die woorde van Jesus en die Ou Testament kan ons in drie groepe indeel naamlik: sitate, ,citations," wat die gedagtes van die Ou Testament woordeliks of byna woordeliks weergee; dan sinspelinge „Anspielungen," „allusions" wat wel die gedagte-inhoud weergee, maar in wesenlik afwykende woorde; en in die derde plaas herinneringe, „Reminiscenzen," „reminiscenses" wat nog net aan die gedagte in die $\mathrm{Ou}$ Testament herinner. 26)

Dit is nie moontlik om hier 'n tabel weer te gee nie, maar ons kan slegs die konklusies gee wat op grond van so'n tabel gemaak kan word. Dit is met die eerste oogopslag duidelik dat Jesus ryklik van die Ou Testament gebruik gemaak het. 27) Hy het aangehaal uit al drie die hoofdele van die Ou-Testamentiese kanon. 28) Uit sommige boeke het $\mathrm{Hy}$ meer geput as uit ander en-dit bring ons by 'n probleem-uit 'n paar boeke het $\mathrm{Hy}$ glad nie aanhalinge gemaak nie, naamlik Ester, Prediker, Hooglied, Josua, Obadja, Haggai en Rut. Die ontleninge aan II Samuel, Nahum, Sefanja, Esra, Nehemia, I Kronieke is twyfelagtig daar hulle netsowel uit ander boeke geneem kon wees. Maar die aanwesigheid van Josua in die kanon word verseker deur die feit dat 'n kanon wat Deuteronomium en Rigters insluit, nie sonder Josua sou bestaan nie. II Samuel word gedra deur I Samuel, want die skeiding tussen I en II het eers in die sestiende eeu in die Hebreeuse Bybel gekom. Desgelyks is die posisie wat I en II Kronicke betref. Vir die teenwoordigheid van Obadja, Nahum, Sefanja en Haggai getuig die ander klein profete van die Klein-Profetebock. 29) Van Rut vind ons paralelle in die geslagsregisters by Mattheüs en Lukas. Vir die insluiting van Esra en Nehemia het ons bewys in die feit dat die soortgelyke Kroniekeboeke ingesluit is. Van almal bly daar dus net Prediker, Hooglied en Ester oor wat nie op een of ander wyse 
verantwoord kan word nie. Merkwaardig is dat juis oor dié boeke deur die Jode diskussies gevoer is. Prediker kan maklik as wêreldse pessimistiese bespiegelinge beskou word, Hooglied as erotiese liefdesliriek en Ester as 'n produk van die Joodse partikularisme en wraakgierigheid. Wanneer dit dan wil voorkom dat Jesus dié drie boeke uit sy prediking uitsluit, kan dit die indruk wek dat ook Hy oor diẻ boeke só 'n beskouing gehuldig het.

Om die probleem waarvoor ons hier staan, na die subjek te verlê deur te beweer dat sommige boeke vir die bewussyn van die volk ten tyde van Jesus nog nie dieselfde outoriteit besit as die oueres nie, gee geen bevredigende oplossing nie. 30). Om aan te neem dat Jesus oor hierdie boeke liewer geswyg het, omdat hulle in dispuut was in sy tyd, pas nie by die waaragtigheid van die Seun van God nie en kom in die wese van die saak neer op 'n soort kompromis en akkomodasie wat by Hom ondenkbaar is. Die moontlikheid bestaan dat die afwesigheid van aanhalinge uit Prediker, Hooglied en Ester aan sekere onstandighede te wyte is, en daarom mag ons nie meen dat terwyl daar geswyg word, dit 'n veroordeling-dum silent condemnant--beteken nie. 31) Dit is byvoorbeeld moontlik dat die boeke nie vermeld word nie omdat hulle vir Jesus se doel nie in aanmerking kom nie. 32) Ons het reeds melding gemaak van die feit dat buite-Bybeise bronne ons met reg laat verwag dat die kanon van Jesus van gelyke omvang is as die een wat ons bekend is, en dat dit dus ook hierdie drie bewuste boeke ingesluit het. Die vraag bly egter of ons in die woorde van Jesus Self sy bekendheid met die boeke kan aantoon. Ons meen van wel: Hoewel daar geen aanhalinge van Prediker voorkom nie, kan tog sekere reminissense daarvan in die woorde van Jesus aangetoon word, naamlik: Prediker 5: $1=$ Mattheüs $6: 7 ; 7$ : $15 \mathrm{vv} .=$ Mattheüs $6: 1,5 ; 11: 1 \mathrm{vv}$.-Lukas $16: 9 ; 4: 17=$ Lukas 23: 34: 5: 14=Lukas 12:20 en Lukas 16: 23; 7:20 vv. =Mattheüs 7:1 vv. en Lukas $6: 37 ; 6: 3=$ Mattheüs $16: 26 ;$ Markus $8: 36$ 25; $7: \quad 18=$ Lukas $9:=$ Mattheüs $23: 23$; Lukas $11: 42 ; 9: 10$ $=$ Johannes 9:4; 11:5=Johannes $3: 8$. Van Hooglied vind ons vier reminissense, naamlik: 4: 15-Johannes $7: 38 ; 8: 6=$ Mattheus 16: 18; 8: $7=$ Mattheüs 13:44, 46;5:2, $6=$ Lukas 12:36. Toegegee dat hierdie herinneringe nie dieselfde gewig dra as direkte sitate nie, mag die betekenis daarvan egter nie onderskat word en aan die toeval toegeskrywe word nie. Dit toon in elk geval 'n sekere verwantskap tussen die woorde van Jesus en die woorde in dié twee boeke. 33)

Dat Ester in die tyd van Jesus bestaan het, dat Hy die boek geken en stilswygend gesanksioneer het, word bewys uit die gebeurtenis wat 
verhaal word in Johannes 5: 1 waar in die algemeen sprake is van ,'n fees van die Jode" terwille waarvan Jesus na Jerusalem opgegaan het. Noukeurige uitleg van dié teks bring aan die lig dat dit nie die Pinksterfees was nie, 34) nie die Loofhuttefees nie, 35) ook nie die Paasfees nie, 36) maar niks anders as die Purimfees nie. Die bewys hiervoor is die volgende: Die Griekse Christene, vir wie Johannes skrywe, sou nie belang hê by die naam van 'n minderbekende Joodse fees nie; daarom noem hy dit algemeen ,'n" fees. Johannes 4: 35 dui 'n tyd vier maande voor die oesmaand April, dit wil sê Desembermaand, aan. Johannes 6: 4 dui 'n posisie pas voor die Pasga in April aan. 'n Ander Paasfees, Pinkster en Loofhuttefees word uitgesluit omdat dié nie tussen Desember en April kan val nie. Die enigste fees wat wel in dié tyd plaasvind is die Purim in Maart. 37)

Uit alles wat sover voorgelê is, word dit duidelik dat die kanon van Jesus in omvang in elk geval nie kleiner was as die Ou Testament wat ons ken nie. Die vraag is verder of dit miskien groter was as die Palestynse kanon deurdat dit byvoorbeeld sekere apokriewe ingesluit het. Ook hier kom ' $n$ tabel te pas. Ons kan nie ontken dat in die woorde van Jesus 'n sekere gelykluidendheid met "Anklänge" aan sekere apokriewe voorkom nie. Daaroor is die teoloë dit eens met mekaar. Maar hoe groot, dit wil sê hou nou (kwalitatief) en hoe uitgebreid (kwantitatief), die ooreenkoms is, sal grootliks bepaal word deur die uitgangspunt, die dogmatiese vooringenomenheid waarmee die woorde van Jesus gelees word. Want as uitgegaan word van die woorde van Jesus en ooreenstemminge met die apokriewe gesoek word, sal 'n grenslose tabel verkry kan word. Tabelle sal verskil van persoon tot persoon. Ook wat dié saak betref is dit nie moontlik om hier ' $n$ tabel aan te bied nie. Ons kan weer net die konklusies op grond van so 'n tabel voorhou:

Daar is veral twee kontroversiële tekste naamlik Johannes $7: 38$ en Lukas 11: 49. Eersgenoemde teks word deur sommige verklaarders beskou as 'n aanhaling uit 'n apokriewe boek wat vir ons verlore gegaan het, maar hoewel dit apokrief is, so gaan hul voort, het die skrywer geglo dat hy 'n kanonieke boek aanhaal en dié voorbeeld sou deur baie NuweTestamentiese skrywers nagevoly wees. 38) Maar ons het reeds aangetoon dat hoewel Johannes 7:38 geen aanhaling is nie, dit 'n Skriftuurlike gedagte is wat dikwels voorkom. 39) Die plegtige woorde van Lukas 11: 49 maak die indruk van 'n aanhaling te wees. Maar dié aanhaling kan nêrens teruggevind word nie, nóg in die Ou Testament, nógen dit is van belang-in een of ander apokriewe boek. Die vraag is veral wat die betekenis is van: „Daarom het die wysheid van God ook gesê." 
Neem ons die teksverband in aanmerking en vergelyk ons dit met Mattheüs 23: 34 vv., dan is daar geen twyfel dat dit jesus Self is wat spreek as die Wysheid van God nie en dat dit nie 'n aanhaling is uit apokriewe wysheidsliteratuur wat die wysheid personifieer en sprekend laat optree nie.

'n Algemene beskouing van die tabel bring aan die lig: eerstens dat Jesus nêrens 'n uitspraak, wat moontlik uit 'n apokriewe boek kan wees, met 'n plegtige aanhalingsformule inlei nie; ten tweede dat terwyl daar by verband met die Ou Testament onderskei kan word tussen sitate, sinspelinge en reminissense, daar wat die apokriewe betref slegs die monotone reminissense voorkom en dit word daardeur vir die leser onmoontlik om vas te stel of die woorde van Jesus van die apokriewe afhanklik is, dan of die ooreenkoms toevallig is; in die derde plaas dat in elke geval waar in die woorde van Jesus ' $n$ herinnering aan ' $n$ apokrief voorkom, dié herinnering netsowel aan 'n Ou-Testamentiese woord ontleen kon gewees het. (In dié verband moet onthou word dat daar baie gevalle is waar die woorde van Jesus met die Ou-Testament in betrekking tree sónder die konkurrensie van 'n apokrief, en om die rede is dit natuurlik om in die ander gevalle an die Ou Testament bó die rivaliserende apokriewe boek die voorkeur te gee); vierdens dat waar woorde van Jesus verwantskap beide met die O.T. en die apokriewe vertoon, dit opval dat die verband met e.g. veel inniger is as met l.g., ten vyfde dat hoewel daar ook 'n eie goed "Sondergal" in die apokriewe is, dit tog opvallend is dat daar nooit van hierdie kenmerkende eie goed gebruik gemaak word nie; ;40) en ten slotte dat hoewel kanonieke en apokriewe boeke daarin ooreenkom dat uit sommige boeke deur Jesus nie aangehaal word nie, die apokriewe boeke by die kanonieke boeke vér agterstaan wanneer ons die geheel in aanmerking neem en nie let op dic uitsonderinge nie. 41) Die uitsonderinge bevestig die reël van aanhaling by dic kanonieke boeke, iets wat nie van die apokriewe gesê kan word nie.

Ons konklusie kan dus nie anders wees nie as dat die kanon van Jesus nie die apokriewe ingesluit het nie, dat sy kanon dus ook nie groter was as die Palestynse nie, en dat terwyl dit ook nie kleiner is nie, soos reeds aangetoon, dit inderdaad van gelyke omvang as die aan ons bekende Ou-Testamentiese kanon moet wees.

\section{Indeling en Rangskikking.}

Uit Lukas 24: 44 was reeds durdelik dat Jesus 'n driedelige kanon geken het. 42) Het ons dit eenmaal vasgestel, dan is die volgende vraag: Hoe is die verskillende boeke ingedeel in die drie groepe en hoe is hulle gerangskik binne die groepe? "Wet" is eenvoudig wat tot dié 
groep het slegs die wet van Moses behoort. Tot die groep "Profete" hoort natuurlik die voorspellend-profetiese en die histories-profetiese boeke nl. Jesaja, Jeremia, Klaagliedere, Esegiël, Klein-Profete en dan Josua, Rigters, Rut, Samuel, Konings, Kronieke, Esra-Nehemia, respektiewelik. Tot die "Himnes"-groep behoort in die eerste plaas natuurlik Psalms en Spreuke, dan verder ook Prediker en Hooglied omdat hulle van Salomoniese outeurskap is (of ten minste op Salomoniese wyse geskrywe is as ons die Hebreeuse lamed op dié manier wil verstaan) en omdat hulle self ook sekere poëtiese gedeeltes bevat. Ons kan byvoeg dat in die kanon-geskiedenis die vier boeke dikwels as 'n eenheid saamgegroepeer is. 43 )

Moeiliker is die vraag hoe die boeke binne die groepe gerangskik is. Ons insiens is dit nie uit te maak nie. 'n Oorweldigende veelheid van kommentatore vind in Mattheus 23: 25 ' $n$ aanduiding van kanoniese volgorde. Hier is naamlik sprake van die dood van Sagaria, die seun van Beregja wat omgekom het tussen die reukaltaar en die huis van God. Onder diẻ Sagaria word die Sagaria van II Kronieke 24: 20 vv. verstaan en Kronieke word dan as die laaste boek in die kanon beskou, terwyl die vermelding van die dood van Sagaria tog nie kronologies die laaste kan wees nie, aangesien dit reeds ongeveer 800 v.C. moes plaasgevind het. 44) Hierdie opvatting word egter gedruk deur die beswaar dat die bewuste Sagaria van Il Kronieke die seun van Jojada genoem word (en nie die seun van Beregja soos deur Jesus in Mattheüs nie) en dat dié feit nie bevredigend verklaar kan word nie. 45) En, al sou dit vasgestel kon word dat die moord uit II Kronieke bedoel is, is daar nog geen regverdiging om uit dié feit konklusies aangaande kanoniese volgorde te trek nie. Die vermelding van juis Abel en Sagaria kan ook om ander redes wees nl. die ooreenkoms dat die bloed van beide geroep het tot God, of die feit van die skéndige steniging van Sagaria want dit het in die voorhof van die tempel plaasgevind. 46)

\section{Die Tekskarakter van die Ou Testament van Jesus.}

Algemeen word aangeneem dat in die dae van Jesus se omwandeling en optrede in Palestina daar drie tale bekend was, naamlik Hebreeus, Aramees, en Grieks, met Latyn in 'n mindere rol. In die burgerlike lewe het Aramees alle ander tale verdring en die landstaal geword sodat die wêreld waarin Jesus beweeg het, Aramees as omgangstaal gebruik het. Terwyl dit die geval is, spreek dit vanself dat Jesus in die Aramese taal opgevoed is, dat Hy tot sy dissipels en die volk in Aramees moes spreek om verstaan te word. „Daar hoef dus geen twyfel meer te bestaan nie dat die Kind Jesus aan moedersknie die eerste taalklanke in Aramees opgevang het en ook sy ecrste gebede in hierdie taal gebid het." 47) 
Aramese invloede, selfs Aramese woorde en sinne, in die Griekse Evangelies is nie weg te redeneer nie. Daar is ook 'n Aramese psalmvers uit die mond van Jesus opgeteken, naamlik Markus 15: 34 en hierin herken ons die taalsoort waarin die siel van Jesus hom beweeg het en waarin $\mathrm{Hy}$ biddend met sy God omgegaan het. 48.. Of die Skrif, objektief, búite Jesus, ook in Aramees bestaan het, is nie af te lei uit dié teks alleen nie. Ons moet eers nog let op 'n ander groep feite:

Blykens die Griekse teks het daar sterk invloed van die sogenaamde „Septuaginta" (Griekse vertaling van die Ou Testament en apokriewe), soos ons dit vandag ken, uitgegaan op die hele Nuwe Testament, in besonder wat betref die Evangelies, op die Ou-Testamentiese sitate deur die Evangelieskrywers self gemaak en op die aanhalinge wat hulle van Jesus opgeteken het. 49) Dit is alles waar van die Griekse teks soos ons dit vándag ken. Gaan ons egter in die teksgeskiedenis van die Evangelies terug na die oudste bereikbare vorm, dan blyk dit dat daar 'n aan die „Septuaginta" vreemde trek in die sitate van Jesus lê. 50) Voeg hierby dat die sogenaamde Septuaginta eintlik 'n onbekende entiteit is. 51) Om dus te beweer dat die aanhalinge wat Jesus uit die $\mathrm{Ou}$ Testament maak uit 'n "Griekse Bybel” geneem is, is nie bewysbaar nie. Terwyl dit die geval is en terwyl die moedertaal van Jesus Aramees was, moet ons dus die Bybel van Jesus eerder soek onder die Semitiese versiones en dit bring ons terug by die slotsinne van ons vorige paragraaf.

Dat dit waarskynlik nie 'n Hebreeuse Bybel was waaruit Jesus sy aanhalinge uit die Ou Testament gemaak het nie, word gestaaf deur die feit dat die aard van die Jesussitate volgens die oudste Griekse teks, ook teen die Massoretiese (Hebreeuse) teks gaan en daardeur teen die Pesjitta (Siriese vertaling) wat noú aansluit by die Massoretiese teks. 52) Daar bly alleen maar die moontlikheid oor dat Jesus 'n Aramese Bybel aangehaal het by gebruikmaking van die Ou Testament. Dit pas goed in in die raamwerk van die feite reeds genoem en word nog verder gestaaf deur die feit dat volgens die oudste Griekse teks die Jesussitate groot ooreenkoms vertoon met die Aramese Targum. 53) Dat so 'n Aramese Bybel bestaan het word bewys uit die rabbinistiese literatuur, 54) uit die „Septuaginta," 55) en uit die Ou Testament self, naamlik die Aramese gedeeltes van Daniêl. 56) By alles moet ons onthou dat watter Bybel ook al beskikbaar gewees het, Jesus die Skrifrolle nie met Hom saamgedra het nie-dit is ondenkbaar. Bowedien kan ons ons dit cok moeilik voorstel dat Jesus terwyl Hy die volk en sy dissipels in Aramees toespreek, sou oorslaan na Hebreeus wanneer Hy uit die Ou Testament aanhaal. Omdat Hy die Woord in Sy binneste gedra het, het Hy natuurlik wanneer $\mathrm{Hy}$ aanhaal meestal die gedagte-inhoud met verbygaan van die letterlik geskrewe 
teks, weergegee. En terwyl Hy alleen die gedágtes weergee sou Hy dié nie in Hebreeus nie, maar in dieselfde Aramees waarin Hy spreek, in die loop van sy rede invoeg.

Alles tesame in aanmerking genome, moet ons konkludeer dat die waarskynlikste tekskarakter van die Bybel van Jesus Aramees was. 57)

\section{Afgeslotenheid en Afsluiting van die Kanon volgens Jesus.}

Met afgeslotenheid word die prinsipiële afronding en met afsluiting word die afsluitingsdatum bedoel. Gegewens oor eersgenoemde word ontleen aan die woorde van Jesus en gegewens oor laasgenoemde lê op die kanon-historiese gebied. Op laasgenoemde gaan ons eerste in om só 'n agtergrond te vind waarteen ons die woorde van Jesus moet lees.

a) Afsluiting van die kanon: Wat die afsluitingsdatum betref kan ons sê: Soveel hoofde, soveel sinne-quot homines tot sententiae. Tog kan ons die veelheid van gevoelens in twee groepe verdeel, naamlik dié wat die afsluitingsdatum een of ander tyd vóór Christus vind en dié wat die afsluiting ná Christus, met name by die sinode van Jamnia, stel. Vir ons ondersoek is slegs laasgenoemde van betekenis, want as dit inderdaad ' $n$ feit is dat die Ou-Testamentiese kanon eers by die sinode van Jamnia (90 ná Christus) afgesluit is, kon Jesus geen afgeslote kanon geken het nie. Die vraag is dan: Wat is die betekenis van die sinode van Jamnia?

Dit is van belang om te weet dat op die sinode debat gevoer is, o.m. oor Esegiël, Spreuke, Hooglied en Ester, maar-en dit is van groot betekenis--die diskussies het nie soseer gegaan oor die toelating van die boeke tot die kanon nie, as oor hulle reg om in die kanon te bly. 58) Ons kan byvoeg dat nóg die sinode van Jamnia, nóg enige ander sinode boeke kan „kanoniseer” nie, want die boeke word nie kanoniek deurdat hulle as sodanig deur die mense erken word nie, maar hulle dra van die begin af die tekens van kanonisiteit aan hulle self, al word hulle eers later deur die mense as kanonick erken en versamel. 59)

Op grond van dié betekenis van die sinode van Jamnia en op grond van die buite-Bybelse gegewens waarna verwys is onder afdeling II, kan ons dus verwag dat Jesus 'n afgeslote kanon voor hom gehad het.

b) Afgeslotenheid van die kanon: Wanneer Jesus „wet” (nomos) in die enkelvoud in Mattheüs 23: 23; Lukas 10: 26; Johannes 10: 34; en 15: 25 gebruik, dan lê hierin die gedagte van 'n afgeslote geheel opgesluit. Ander name mag die veelheid van die Skrifte aandui, maar hierdie benaming in die enkelvoud wys nie alleen op die eenheid van die Skrifte nie, maar ook op hulle geheelheid, die feit dat hulle 'n afgeslote eenheid is. Ons sou dit kon nocm hul „Einheit” en „Einheitlichheit.” 
Dieselfde konklusies as in voorgaande kan ons uit die gebruik van „die Skrif" (grafê) in Johannes 10: 35 aflei. Hier gebruik Jesus „Skrif” as aanduiding van die hele Ou Testament. Dit wys op 'n afgeslote eenheid. Wanneer nog bygevoeg word dat dit ,nie gebreek kan word nie," is die getuienis dubbel sterk dat Jesus 'n afgeslote, afgeronde eenheid bedoel het.

Die konsekwente uitsluiting van die apokriewe boeke (vergelyk afdeling II), sommige waarvan (soos die Spreuke van Jesus Sirach en Makkabeërs) in verskillende opsigte van hoogstaande gehalte is, kan alleen verstaan word as ons anneem dat die Ou-Testamentiese Bybel reeds 'n afgeslote, afgeronde struktuur was. 60 )

Jesus het geweet dat Hy die vervulling is van wat in die Ou-Testament?ese Skrifte voorspel is (vgl. Mattheus 26: 54 en baie ander plekke).

Hy kom om die Skrifte te vervul (vgl. Mattheüs 5: 17 vv.). Om dié rede moet ons aanneem dat die Skrifte van die Ou Verbond hulle doelpunt reeds bereik het, dat die hele fondament waarop die nuwe gebou sou verrys, klaar gelê is. In die esgatologie is daar die idee van 'n nuwe epog wat aanbreek, met Jesus op die voorgrond. Dit hou in dat die ou aeoon hom na sy volheid moes ontvou het. Die profesie in verband met die toekoms moes ook eers tot volle ontplooiing gekom het, vóórdat daar 'n vervulling van dié profesie kon wees.

Al hierdie oorweginge spreek daarvoor dat Jesus 'n afgeslote, afgeronde kanon gehad het.

Heidelberg, Tvl.

\section{S. J. DU PLESSIS.}

(Word vervolg).

(1) A. Oepke: Jesus und das Alte Testament p. 4 en 5.

(2) G. Ch. Aalders: Bybelsch Handboek O.T., p. 329.

F. W. Grosheide: Algemeene Canoniek van het N.T., p. 4.

A. Bentzen: Introduction to the Old Testament, p. 20.

J. D. du Toit: Die Bybel is die Woord van God, p. 4.

(3) W. Urwick in Biblico-Theological Levicon of the N.T. van H. Cremer, p. iii.

(4) A. Deismann: Licht vom Osten, p. 51.

(5) S. C. Schirlitz: Grundzüge der Neutestamentlichen Gräcität, p. 13, 14.

(6) Schirlitz a.w. p. 13, 14.

G. Dalman: Die Worte Jesu, p. 1-5.

(7) F. W. Grosheide: Hermeneutik, p. 139.

A. Kuyper: Encyclopaedie III, p. 82 v.p.

(8) A. Kuyper: Encyclopaedie II, p. 181.

J. M. S. Baljon: Grieksch Theologisch Woordenboek I, p. 473. 
Cremer: Biblisch-Theologisches Wörterbuch der Neutestamentlichen Grazität, p. 265.

(9) Baljon, a.w. p. 473.

Cremer, a.w. p. 265.

E. Hünn: Die alttestamentlichen Zitate und Reminiscenzen im Neuen Testamente, p. 276.

A. Clemen: Der Gebrauch des Aiten Testaments in dem Neutestamentlichen Schrifte, p. 37.

Th. Zahn. Das Evangelium des Johannes, p. 393.

(10) C. Bouma: Het Evangelie naar Johannes, .p122, 123.

Bousset en Heitmüler: Das Johannes-Evangelium, usw. p. 111.

J. P. Lange: Das Evangelium nach Johannes, p. 257.

Strack \& Billerbeck: Das Evangelium nach Johannes, p. 492.

H. A. W. Meyer: Das Johannes-Evangelium, p. 307.

J. A. Bengel: Gnomon of the New Testament, p. $345,346$.

H. Olshausen: Commentary on the Gospels, etc. Vol. III, p. 486.

F. Junius: Verklaringe en Betooginge der Heilige gelykluidende Texsten die uit het O.T. in het geheel N.T. worde aangehaelt, vertaal deur J. A. Tierens, p, 273.

Th. Zahn: Johannes-Evangelium, p. 393.

(11) Cremer, a.w. p. 166.

Baljon, a.w. I, p. 473.

Bauer, a.w. p. 260.

G. Kittel: Theologisches Worterbuch zum N.T.I. p. 751.'

H. A. Ch. Hävernick: Handbuch der historisch kritischen Einleitung in das Alte Testament I, p. 77.

J. Hänel: Der Schriftbegriff Jesu, p. 18, 19.

(12) Hänel, a.w. p. 19, 20.

(13) Kittel a.w. III, p. 1051.

(14) K. Budde: Der Kanon des Alten Testaments, p. 49

(15) Hänel a.w. p. 22, 23.

(16) Weiss \& Bousset: Die drei älteren Evangelien, p. 511.

(17) G, Wildeboer: Het ontstaan van den Kanon des ouden Verbonds, p. 47.

(18) Meyer: Die Evangelien des Markus und Lukas, p. 689.

(19) Hänel a.w. p. 24, 25, 26.

(20) Vele Kommentatore-te veel om op te noem.

(21) Ph. S. van Ronkel: Specimen Philologicum exhibens Jesu Christi Doctrinam de veteris foederis libris, etc. p. 74

(22) Hänel a.w. p. 26.

(23) Hänel a.w. p. 27.

(24) Hävernick a.w.I. p. 79. Hänel a.w. p. 28.

(25) In die Rabbinistiese literatuur gaan dit veral oor die twee veelomstrede uitdrukkinge ..boeke wat dic hande nie verontreinig nie," en ,boeke wat verborge is." Ons verwys die leser hiervoor na die werk van Hanel. 
(26) Hänel $a|w| p .34,35$.

W. Dittmar: Vetus Testamentum in Novo.

H. B. Swete: Introduction to the Old Testament in Greek, p. 381.

F. Barth: Die Hauptprobleme des Lebens Jesu, p. 79.

(27) Hänel, a.w. p. 77 v.p

J. J. P. Valeton: Christus en het Oude Testament, p. 18; p. 28.

(28) Ronkel, a.w. p. 47.

(29) Hänel, a.w. p. 45.

J. H. Raven: Old Testament Introduction, general and special, p. 19.

(30) Schürer, aangehaal deur Hänel, p. 33.

(31) M. Noordtzij: De Leer van Jesus en de Apostelen over de $H$. Schrift des O.T., p. 9.

J. G. Eichhorn: Einleitung in das Alte Testament, erster Band, p. 140.

(32) Hänel, a.w. p. 33

F. Buhl: Kanon und Text des alten Testaments, p. 17, 49, 50.

H. L. Strack: Kanon des Alten Testaments in Realencyklopädie, Neunter Band, p. 748, 750 .

(33) Hänel, a.w. p. 46.

(34) Bengel, a.w. II, p. 302.

(35) Th. Zahn: Johannes-Evangelium p. 277, 278.

(36) Vergelyk C. Bouma a.w. p. 173.

Zahn a.w. p. 277.

(37) Hänel aiw. p. 48

Meyer: Johannes Evangelium p. 193, 194.

Olshausen a.w. III p. 426, 427.

Lange: Johannes p. 180.

(38) Huhn a.w. p. 270;

Budde a.w. p. 73.

Bauer a.w. p. 113.

Fr. Bleek: Uber die Stellung der Apokryphen des Alten Testaments im Christlichen Kanon. Artikel uit: Theologische Studien und Kritiken herausgegeben von G. Ullman und F. Umbreit p. 332.

R. H. Pfeiffer: Introduction to the Old Testament p. 66 .

(39) J. H. Bernard: A Critical and Exegetical Commentary on theh Gospel according to St. John vol. I, p. 281; "The idea of v. 38 is scriptural."

(40) Hänel a.w. p. 69-72.

(41) W. Fell: Lehrbuch der Allgemeine Einleitung in das Alte Testament, p. 57.

E. Sellin: Einleitung in das Alte Testament, p. 178.

(42) 'n Groot getal kommentatore is dié mening toegedaan-te veel om hier op te noem. Vir ons doel is genoeg die woorde van Calvyn (a.w. II p. 407, 408); „Denique hic plenior habetur quam alüs locis Scripturae partitio: quia praeter Legem et Prophetas, tertio loco adduntur Psalmi."

(43) Die vier boeke is saamgegroepeer in die Septuaginta en alle Bybels wat laasgenoemde volg vgl. Hänel a.w. p. 90, 91 en Swete a.w. p. 201 en 214.

(44) Hierdie is ' $n$ tradisionele opvatting wat deur baie verklaarders gehuldig word-te veel name om hier weer te gee. 
(45) Baie pogings word aangewend-te veel om hier op in te gaan-maar nie een kan ' $n$ bevrediggende oplossing gee wat nie op een of ander kunsmatige uitleg berus nie.

(46) Calvyn a.w. II p. 254

Meyer: Mattheus p. 400.

K. Budde a.w. p. 57, 58.

(47) S du Toit: Die Moedertaal van Jesus en Sy Apostels, „Koers," Deel XI. Nr. 3, p. 82.

G. Dalman: Die Worte Jesu p. 9 en 19.

Th. Zahn: Einleitung in das Neue Testament I, p. 4.

E. Schürer: A History of the Jewish People in the time of Christ. Translated by S. Taylor and P. Christie. Second Division, vol. I, p. $8,9$.

(48) Zahn a.w. I, p. 2.

(49) Swete a.w. p. 392, 403 en veral p. 404 en 450.

(50) Hänel a.w. p. 108;

Swete a.w. p. 393 vp.

Dittmar: Vetas Testamentum in Novo.

(51) Dit is die opspraakwekkende beskouing van P. Kahle: The Cairo Geniza. Hy word met akklamasie aangehaal deur A. Benzen a.w. p. 82, 83 Vergelyk ook Pfeiffer a.w. p. 105 en 107.

Oesterley and Robinson: : An Introduction to the Books of the Old Testament, p. 8.

H. L. Strack: Kanon des Alten Testament in Realencyklopädie IX, p. 754 waar hy spreek van: „Der sogenannte alexandrinische Kanon."

(52) Hänel a.w. p. 138.

P. Kahle a.w. p. 183: Die feit van die afwyking van die Hebreeuse teks stem ooreen met die gebruik in daardie tyd naamlik dat in die sinagoge nog wel uit Hebreeus voorgelees is, maar dat 'n „Verdolmetscher" dit in Aramees oorgesit het vgl.

Oesterley and Robinson a.w. p. 12;

Hänel a.w. p. 137 ; ; en

G. Dalman: Jesus-Jeschua, p. 37 .

(53) Hänel a.w. p. 138-140;

Zahn: Mattheus p. 624;

Zahn: Einleitung II. p. 318. Hulle ontleen die argumente veral aan Mattheus 21: 16.

(54) L. Goldschmidt: Der Babylonische Talmud I p. 786; p. 31, 32; IV p. 105, 112.

(55) Hänel a.w. p. 143.

(56) G. Ch. Aalders: Het Boek Daniël p. 30.

(57) J, H. Kroeze: De Jeruzalemsche Boekrollen, Koers Deel XVIII. Nr. 3 p. 101 v.p.

(58) O. Eissfeldt: Einleitung in das Alte Testament unsw. p. 624;

A. Bentzen a.w. p. 31 .

(59) J. D. du Toit a.w. p. 17;

Bavinck: Gereformeerde Dogmatiek I. p. 634.

(60) Hanel a.w. p. 101, 102. 